\title{
REGULATION OF THE GLUCOCORTICOID RECEPTOR MRNA LEVELS IN THE GILLS OF ATLANTIC SALMON (SALMO SALAR) DURING SMOLTIFICATION.
}

\author{
D. mAZURAIS (1), B. DUCOURET (1), M. TUjague (1), Y. VALOtAiRe (1), \\ H. D'COTTA (2), C. GALlAIS (2), P. PRUNET (2)
}

(1) Endocrinologie moléculaire de la reproduction, UPRES-A CNRS 6026, IFR de Biologie et Ecologie des Poissons de Rennes, Université de Rennes 1, Campus de Beaulieu, 35042 Rennes, France.

(2) INRA, Laboratoire de Physiologie des Poissons, IFR de Biologie et Ecologie des Poissons de Rennes, Campus de Beaulieu, 35042 Rennes, France.

\begin{abstract}
The regulation of the Glucocorticoid Receptor (GR) transcript was investigated in the gills of Atlantic salmon (Salmo salar) during the parr-smolt transformation. Sampling of parr and smolt fish was performed between December and July and in particular during the smoltification period occurring in spring. Quantification of GR transcripts revealed differences between the two groups in March and at the beginning of April. During these dates, the amounts of GR mRNA in parr gills were respectively three and two fold lower than those measured in smolts. In order to determine which factors are responsible for these differences, we studied the long-term effects of prolactin and cortisol treatments on GR transcript in the gills of presmolt fish. The plasma levels of these two hormones respectively drop and rise during smoltification. Contrary to cortisol long-term treatment which did not modify the amount of gill GR transcript, short-term treatment induced a significant decrease within 12 hours. Prolactin long-term treatment caused a significant increase of GR transcript abundance after 13 days of implant treatment. This result is unexpected with regard to those obtained in the smoltification analysis but is in agreement with previous studies performed in mammary gland revealing a positive control of PRL on GR in epithelial cells. Our data suggest that the regulation of the GR transcript during the parr-smolt transformation probably involves several hormonal factors.
\end{abstract}

\section{RÉGULATION DE L'EXPRESSION DU GĖNE CODANT POUR LE RÉCEPTEUR AUX GLUCORTICOÏDES DANS LES BRANCHIES DE SAUMON ATLANTIQUE (SALMO SALAR) DURANT LA SMOLTIFICATION.}

\section{RÉSUMÉ}

La régulation de l'expression du gène codant pour le récepteur aux glucocorticoïdes (GR) dans les branchies de saumon atlantique (Salmo salar) a été étudiée durant la période de smoltification. Les prélèvements chez les poissons parrs et smolts ont été réalisés entre décembre et juillet et plus particulièrement pendant la phase de smoltification au printemps. La quantification du transcrit GR a révélé des différences significatives entre 
les deux groupes en mars et début avril. Durant ces périodes, les quantités d'ARNm GR dans les branchies de saumons parrs sont respectivement trois et deux fois plus faibles comparées à celles mesurées chez les saumons smolts. Dans le but de déterminer quels facteurs interviennent dans ces variations, nous avons étudié les effets à long terme de traitements à la prolactine et au cortisol sur la quantité de transcrits GR dans les branchies de saumons presmolts. Les concentrations plasmatiques de ces deux hormones chutent et augmentent respectivement durant la période de smoltification. Contrairement au traitement à long terme du cortisol qui n'a pas modifié la quantité d'ARNm GR, un traitement à court terme par cette même hormone induit une baisse significative des taux de transcrits GR à partir de 12 heures de traitement. D'autre part, un traitement à long terme par la prolactine provoque une augmentation significative des taux de transcrits GR à partir de 13 jours de traitement. Ce résultat, allant à l'encontre de ceux obtenus dans l'analyse de la phase de smoltification, est en accord avec les résultats obtenus dans des lignées de cellules épithéliales de glandes mammaires qui démontrent un contrôle positif de la prolactine sur la quantité de récepteurs GR. Nos résultats suggèrent donc que de multiples facteurs doivent probablement intervenir dans la régulation survenant sur la quantité d'ARNm GR branchiale durant la smoltification.

\section{INTRODUCTION}

In anadromous salmonids, the acquisition of salinity tolerance is an important developmental event, occurring during the parr-smolt transformation (smoltification), a preparatory process for downstream migration and seawater entry. During the smoltification process, a complex series of physiological, morphological and biochemical changes occur. Many important changes are developed in the gills, including increases in chloride cell size, number and in the $\mathrm{Na}^{+} / \mathrm{K}^{+}$ATPase activity, which is strongly correlated with increased salinity tolerance (HOAR, 1988). The circulating levels of a number of hormones such as growth hormone $(\mathrm{GH})$, prolactin (PRL), or cortisol are altered during the parr-smolt transformation in different salmonid species (YOUNG et al., 1989 ; PRUNET et al., 1989 ; BOEUF, 1993). PRL levels decrease during this period whereas plasma GH and cortisol levels are elevated, coinciding with a high hypo-osmoregulatory ability. In addition, some hormonal treatments performed on presmolts increase their ability to adapt to hyperosmotic environment. GH treatment increases this adaptation ability through an enhancement of the gill $\mathrm{Na}^{+} / \mathrm{K}^{+}$ATPase activity (BOEUF et al., 1990, 1994 ; RICHMAN and ZAUGG, 1987). In vitro studies established a direct effect of cortisol on $\mathrm{Na}^{+} / \mathrm{K}^{+}$ATPase in coho salmon gill tissue (Mc CORMICK and BERN, 1989). In Atlantic salmon, cortisol implants have been reported in some studies to stimulate hypo-osmoregulatory ability with a two to three fold increase in gill $\mathrm{Na}^{+} / \mathrm{K}^{+}$ATPase activity (BISBAL and SPECKER, 1991) whereas in other studies, cortisol treatments applied to presmolts had no effect on their seawater adaptability (BOEUF et al., 1994). More recently, a synergistic effect of $\mathrm{GH}$ and cortisol was shown for salinity tolerance of Atlantic salmon (Mc CORMICK, 1996). PRL is known to be a freshwater adapting hormone and hence should have an antagonistic action on salinity tolerance and inhibit the increase of gill $\mathrm{Na}^{+} / \mathrm{K}^{+}$ATPase activity. This type of effect following PRL treatment has been reported in Oncorhynchus species by Mc CORMICK et al. (1991) and MADSEN and BERN (1992), but in Atlantic salmon, contradictory results were obtained by BOEUF et al. (1994) who observed an increase of enzyme activity after PRL treatment.

Whereas several studies have established the important role of cortisol in the regulation of smoltification, no information is currently available on cortisol receptor changes in target tissues. Indeed, analysis of cortisol receptor levels could reflect the cortisol sensitivity of the tissue, and explain the regulation of some ontogenic steps during smoltification by this hormone. Such receptors have been detected in teleost gill cytosol by binding using tritiated glucocorticoids (SANDOR et al., 1984 ; CHAKRABORTY et al., 1987), 
and recently the glucocorticoid receptor CDNA was cloned from a trout CDNA library (DUCOURET et al., 1995). This new molecular tool allowed us to quantify gill glucocorticoid receptors at the mRNA level. The current study was undertaken to determine whether changes in cortisol receptor (GR) transcript levels occur in the gills during the parr-smolt transformation of Salmo salar, and after presmolt hormonal treatment.

\section{MATERIALS AND METHODS}

\section{Fish}

Atlantic salmon (Salmo salar) originaly from a Norwegian strain (Sundalsora/Matre) were reared at the Drennec Fish Hatchery, Sizun (Brittany, France) in tanks under natural photoperiod. The fish were kept in circulating water and fed a daily ratio of commercial pellets (Aqualim, Nersac, France). Fish were raised in water temperatures which ranged from $7{ }^{\circ} \mathrm{C}$ in winter to $18{ }^{\circ} \mathrm{C}$ in summer. In October, the fish weighting from 24 to 40 grams (parr fish) were transferred to the INRA fish installations in Rennes. We performed the various experiments described below once acclimatation of the transferred fish was complete (12 days). Water temperatures in freshwater ranged from $13{ }^{\circ} \mathrm{C}$ to $14{ }^{\circ} \mathrm{C}$. Feeding was discontinued two days prior manipulation. For each experiment, fish were anesthetized with ethylene glycol monophenyl ether $(0.3 \mathrm{ml} / \mathrm{l})$ (Merck, Germany) and killed by a blow to the head. Gills were collected and rapidly frozen in liquid nitrogen and stored at $-80^{\circ} \mathrm{C}$ until RNA extraction.

\section{Smoltification experiment}

Due to the characteristic bimodality of Atlantic salmon growth during smoltification, fish were divided according to weight into two separate tanks which were subjected to the same environmental conditions : a parr tank and a tank containing the presmolts which undergo the parr-smolt transformation. Fish were sampled at various dates from March to July.

\section{Treatments}

\section{Cortisol short-term treatment}

Intraperitoneal injections of cortisol were performed to presmolts in November 1994. Cortisol injections ( $5 \mu \mathrm{g} / \mathrm{g}$ body weight) in the form of hydrocortisone (4-pregnen-11 $\beta, 17 \alpha, 21$-triol-3,20-dione) (Sigma) were given by first solubilizing it in ethanol $(100 \%)$ and then added to the saline solution with a final ethanol amount of $10 \%$. Saline solutions containing $10 \%$ ethanol were injected as controls. Injection volume was approximately $100 \mu \mathrm{l}$ in both cases. Gills were sampled at 4,12 and 24 hours after injections.

\section{Cortisol long-term treatment}

Cortisol implants were prepared with hydrocortisone (800 $\mu \mathrm{g} / \mathrm{implant/fish})$ in silastic medical paste containing (7:3) silastic/hardener ratio (Dow corning, Michigan). The control implants were prepared with just silastic and hardener paste (adapted from the procedure of BOEUF et al., 1994). The silastic strips had to be incubated overnight at $50{ }^{\circ} \mathrm{C}$ to harden. The strips were implanted in the peritoneal cavity of the fish in November 1994. We performed gills samplings after $11,13,18$ and 26 days of treatment.

\section{Prolactin long-term treatment}

Cholesterol implants of ovine prolactin (PRL) $(250 \mu \mathrm{g} / \mathrm{implant/fish})$ or just cholesterol for controls were prepared using compressed tablets of $5 \mathrm{~mm}$ diameter made using $2 \%$ 
aerosol-200, $1 \%$ Precirol ATO-5 and $95.7 \%$ cholesterol grains (BOEUF et al., 1994). The implants were placed in a small incision of the presmolt cavity, anterior and ventral to the pelvic fin, in November 1994. We performed gills samplings after 11, 13, 18 and 26 days of treatment.

\section{Double strand probe synthesis}

For GR probe preparation, we used a $1.1 \mathrm{~kb}$ insert isolated by $\mathrm{Sph} 1$ digestion of plasmid pUC8 containing the (rtGR) rainbow trout glucocorticoid receptor " $\mathrm{P} 4$ " clone, as previously described (DUCOURET et al., 1995). This $1.1 \mathrm{~kb}$ fragment overlaps the rtGR 3' coding sequence ( $C$ and $E$ domains).

The actin probe synthesis was performed using a rainbow trout actin cDNA fragment of $1.7 \mathrm{~kb}$ inserted in Eco R I site of p Bluescript (KS).

rtGR and rtactin probes were labelled with [ ${ }^{32} \mathrm{P}$ ] desoxy-CTP by the random priming technique. A denaturated DNA fragment (50 ng) was incubated overnight at room temperature in the following buffer : $50 \mathrm{mM}$ Tris- $\mathrm{HCl} \mathrm{pH} 8,5 \mathrm{mM} 2 \beta$ mercaptoethanol, $200 \mathrm{mM}$ HEPES, $20 \mu \mathrm{M}$ dATP, dGTP and dTTP, BSA $(0.4 \mathrm{mg} / \mathrm{ml}), 50 \mu \mathrm{Ci}\left[\alpha^{-32} \mathrm{P}\right] \mathrm{dCTP}$ $(3000 \mathrm{Ci} / \mathrm{mmole})$ and $1 \mathrm{U}$ of Klenow (Boehringer Mannheim). The reactions were stopped by addition of two volumes of water. Probes purification was achieved on a sephadex G50 column to eliminate free nucleotides. The probe activities were determined by Cerenkov count and were around $5.10^{8} \mathrm{cpm} / \mathrm{\mu g}$ DNA.

\section{Slot blot quantification}

Total RNA, extracted from the gills of Atlantic salmon, were prepared using an A.G.P.C. (acid guanidinium thiocyanate phenol chloroforme) method developed by CHOMCZYNSKI and SACCHI (1987).

$5 \mu \mathrm{g}$ of total RNA sample were incubated in denaturating buffer (16.5\% formaldehyde, $20 \mathrm{mM}$ MOPS, $5 \mathrm{mM}$ sodium acetate, $1 \mathrm{mM}$ EDTA, $\mathrm{pH}$ 7) for $15 \mathrm{mn}$ at $65^{\circ} \mathrm{C}$. After dilution (1V/1V) in 20X SSC, the denaturated RNA were spotted onto a nylon membrane (biodyne pall), using a slot blot apparatus as described by CHELEY and ANDERSON (1984), and fixed by UV exposition $(254 \mathrm{~nm})$ for $3 \mathrm{~min}$. Blots were prehybridized for at least four hours at $42{ }^{\circ} \mathrm{C}$ in $50 \%$ formamide, 5X SSC, $0.1 \%$ SDS, $5 \mathrm{X}$ Denhardt, $50 \mathrm{mM} \mathrm{NaH} \mathrm{PO}_{4}, 100 \mu \mathrm{g} / \mathrm{ml}$ denaturated calf thymus DNA. Hybridizing conditions with ${ }^{32} \mathrm{P}$-labelled rtGR $\left(2.10^{6} \mathrm{cpm} / \mathrm{ml}\right)$ were $50 \%$ formamide, $5 \mathrm{X}$ SSC, $0.1 \%$ SDS, $20 \mathrm{mM} \mathrm{NaH}_{2} \mathrm{PO}_{4}, 1 \times$ Denhardt and $50 \mu \mathrm{g} / \mathrm{ml}$ denaturated calf thymus DNA at $42{ }^{\circ} \mathrm{C}$ overnight.

After hybridization, the blots were first washed in 2X SSC and $0.1 \%$ SDS at room temperature (three successive $5 \mathrm{~min}$. washes). The membranes were then washed using a final stringency of $0.1 \times$ SSC and $0.1 \%$ SDS at $55^{\circ} \mathrm{C}$ (three successive $15 \mathrm{~min}$. washes). Blots were exposed at $-80^{\circ} \mathrm{C}$ on an Kodak X-Omat AR X-ray film for one week.

The quantification of the glucocorticoid receptor hybridization was performed by densitometric analysis of the film using a Vernon apparatus. The results were normalized with an actin probe hybridization. Relative GR mRNA levels have been determined using Othe ratio of GR probe levels to actin probe levels.

\section{Northern blot}

For Northern blots, poly $A^{+}$RNA from the gills of Atlantic salmon and rainbow trout were obtained after chromatography of $500 \mu \mathrm{g}$ total RNA on oligo(desoxythymidine) ${ }_{8}$ Tris acryl $M$ (IBF Biotechnics, France). $2 \mu \mathrm{g}$ of poly $\mathrm{A}^{+}$were subjected to agarose gel 
electrophoresis under denaturating conditions. RNA was transferred onto nylon membrane and hybridized in stringent conditions (as described in the slot blot procedure) with the $1.1 \mathrm{~kb}$ rtGR probe. Membrane autoradiography was done with a Kodak X-Omat AR X-ray film for 4 days.

\section{RESULTS}

\section{Northern blot analysis}

In order to demonstrate that our rainbow trout glucocorticoid receptor (rtGR) probe was able to specifically recognize and quantify Atlantic salmon GR mRNA, a Northern blot analysis was performed on poly $A^{+}$RNA from the gills of Atlantic salmon and rainbow trout using the rtGR probe, as described previously. Figure 1 provides evidence of a single GR mRNA species of $7.5 \mathrm{~kb}$ in the gills of salmon, a size similar to that of the mRNA detected in trout. This result shows that the rtGR probe is able to recognize salmon GR RNA and can therefore be used for salmon RNA quantification by slot blot.

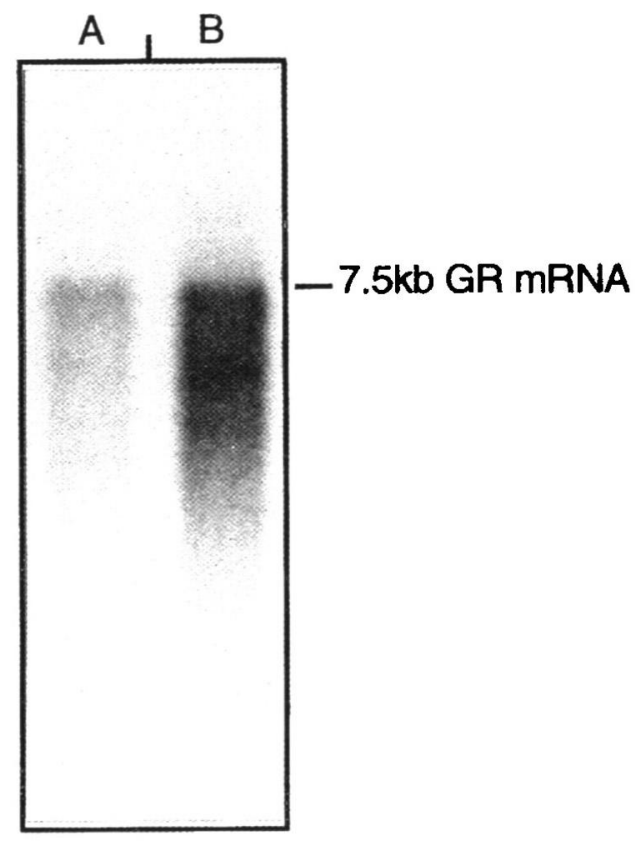

Figure 1

Analysis by Northern blot of the GR transcript in rainbow trout and Atlantic salmon using a rtGR probe.

$2 \mu \mathrm{g}$ of poly A+ RNA from gills of rainbow trout (B) and Atlantic salmon (A) were denaturated, subjected to agarose gel electrophoresis and transferred onto nylon membrane. The membrane was hybridized in stringent conditions with the rtGR probe. Membrane autoradiography was done for 4 days.

\section{Figure 1}

Analyse par Northern blot de I'ARNm GR de truite arc-en-ciel et de saumon atlantique.

$2 \mu \mathrm{g}$ d'ARN poly A+ de branchies de truite et de saumon ont été dénaturés, déposés sur un gel d'agarose et transférés sur une membrane de nylon. La membrane a ensuite été hybridée dans des conditions rigoureuses avec une sonde rtGR. Après lavage, la membrane est placée en autoradiographie pendant 4 jours. 


\section{Short-term effect of cortisol}

Fish manipulation during sampling may cause a stress response to the fish which eventually may affect the levels of the GR mRNA. As it is known that acute sampling stress leads to a fast and important plasmatic cortisol increase, we wanted to determine the effect of a short-term cortisol injection on the GR transcript abundance in the gill tissue. Cortisol ( $5 \mu \mathrm{g} / \mathrm{g}$ body weight) and saline solutions (sham control) were injected into presmolt salmon and the gills were sampled after 4, 12 and 24 hours of treatment. After RNA extraction, we quantified the level of glucocorticoid receptor mRNA by slot blot (Figure 2). A decrease in GR mRNA content was observed 4 hours after cortisol injection and this decrease became significant after 12 hours.

\section{GR mRNA levels} (arbitrary units)

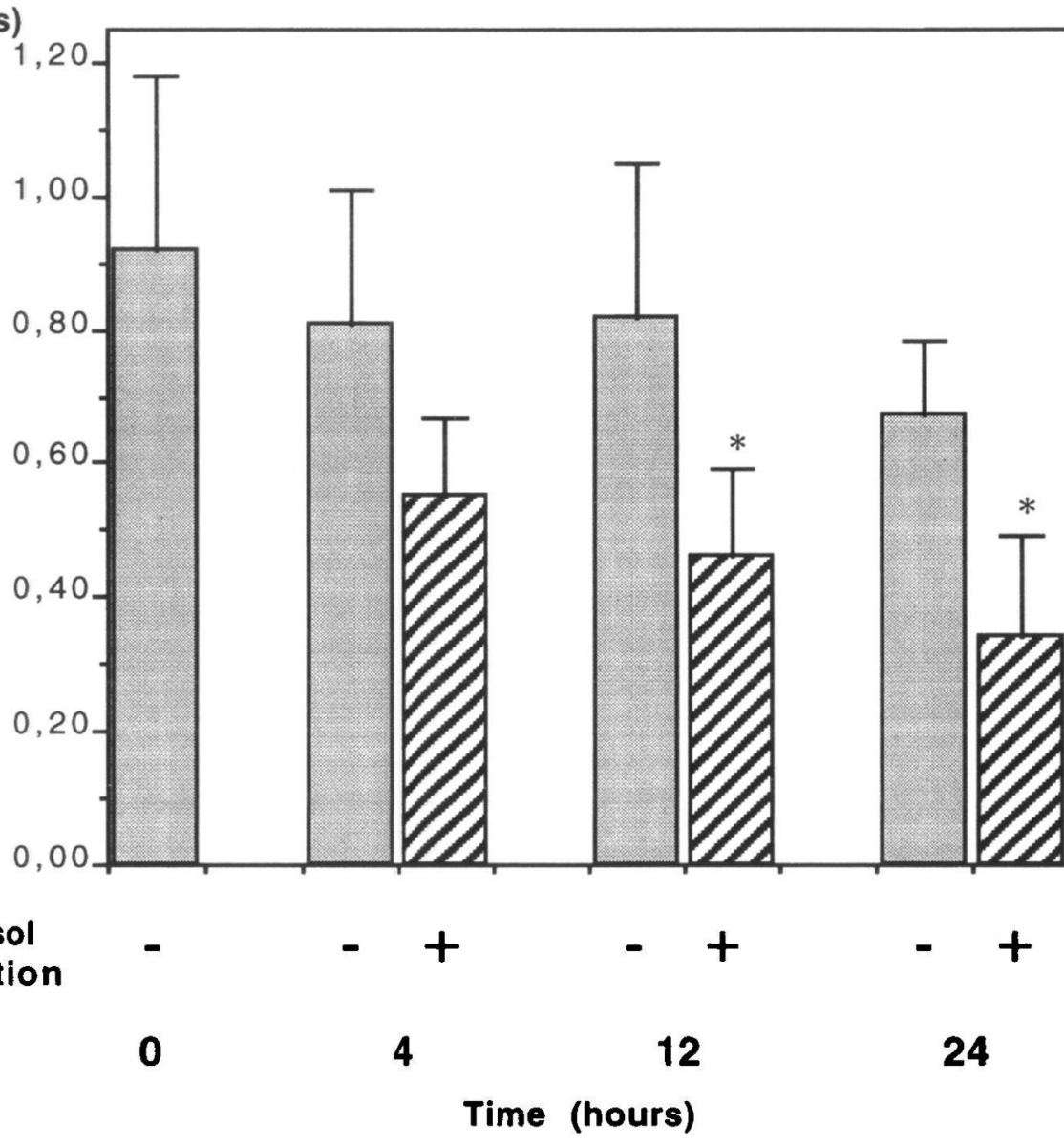

Figure 2

Short-term study of cortisol injection effects $(5 \mu \mathrm{g} / \mathrm{g}$ body weight) on glucocorticoid receptor mRNA levels in the gills of presmolt Atlantic salmon (Salmo salar). Bars represent mean +/. SEM of 4 observations. * : significantly different from the sham.

\section{Figure 2}

Etude des effets à court terme d'une injection de cortisol sur les taux d'ARNm GR dans les branchies de saumons atlantiques presmolts. Les barres d'erreurs représentent l'écart standard à la moyenne sur 4 échantillons. * : significativement différent, comparé au témoin. 


\section{Smoltification}

The amount of GR transcript in gill tissue was quantified at various dates between December and July in parr and presmolt Atlantic salmon reared in freshwater. The samplings were performed in December, March, beginning and end of April, June and July (Figure 3). Quantification of GR transcripts revealed significant differences between parr and smolts in March, as well as at the beginning of April $(p<0.05)$. In March and at the beginning of April, the amounts of glucocorticoid receptor RNA in parr gills were respectively three and two fold lower than those measured in smolts.

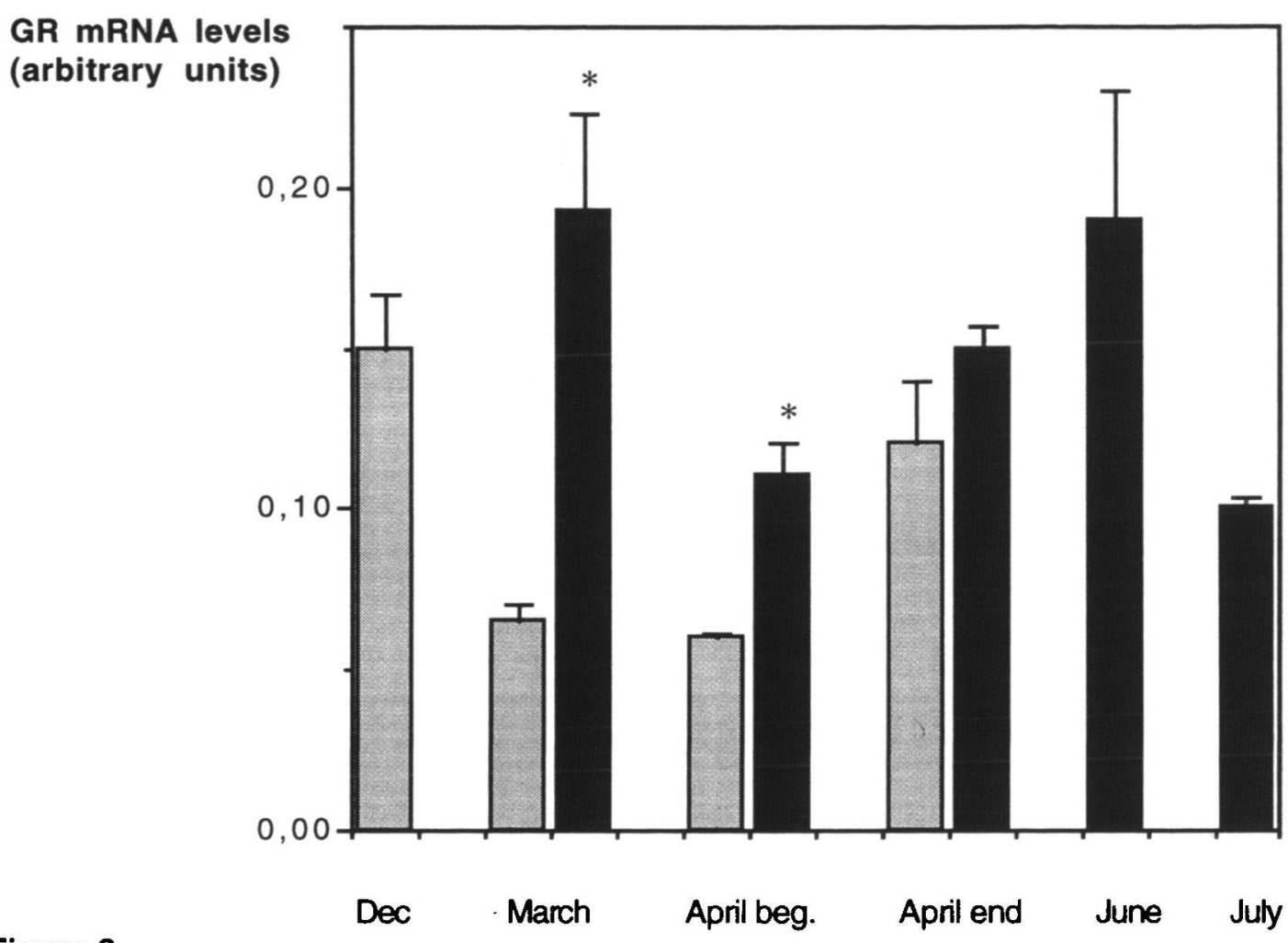

Figure 3

Study of variations of glucocorticoid receptor mRNA during the smoltification in the gills of parr (grey columns) or smolt (presmolt, smolt, postsmolt) Atlantic salmon (Salmo salar) which are going to smoltificate in the year (dark columns). Bars represent mean $+/-$ SEM of 4 observations. * : significantly different $(p<0.05)$ from the parr at the same period.

\section{Figure 3}

Etude des variations des taux des ARNm GR durant la smoltification dans les branchies de saumons parrs (colonnes grises) ou de saumons smoltifiant dans l'année (colonnes noires). Les barres d'erreurs représentent l'écart standard à la moyenne sur 4 échantillons. ${ }^{\star}$ : significativement différent, comparé au témoin.

\section{Long-term effect of prolactin and cortisol}

Prolactin treatment was applied using cholesterol implants to Atlantic salmon presmolts in November (Figure 4). Gills were sampled 11, 13, 18 and 26 days after the beginning of the treatment. Whereas no significant variations of GR mRNA levels were detected in the sham control, a significant increase was observed in PRL-treated fish after 13 days of treatment $(p<0.05)$. GR transcript levels were two fold higher in the treated group than in the control group at 13,18 and 26 days after implantation. 


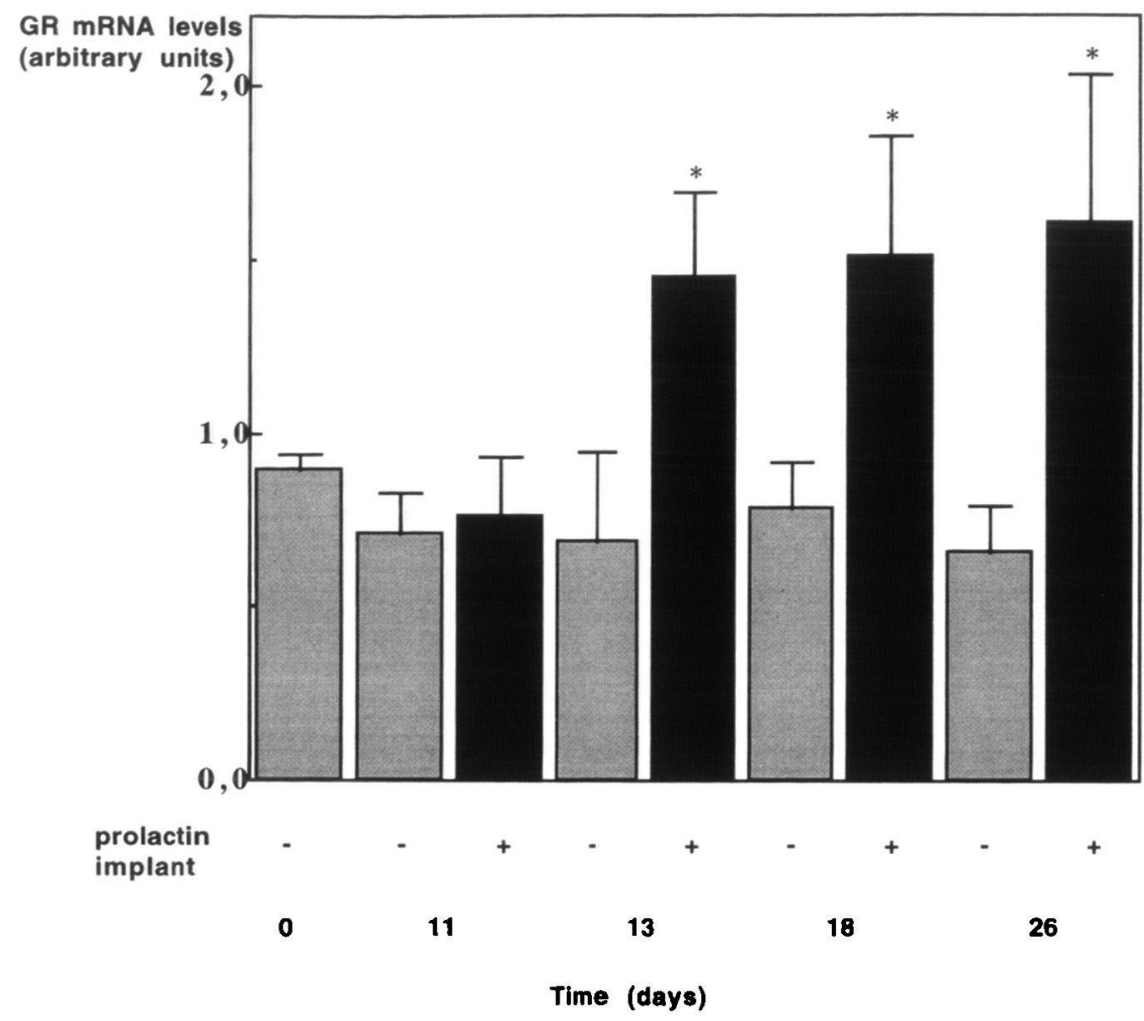

Figure 4

Long-term study of prolactin implant effects $(250 \mu \mathrm{g} / \mathrm{fish})$ on glucocorticoid receptor mRNA levels in the gills of presmolt Atlantic salmon (Salmo salar). Bars represent mean $+/$ - SEM of 4 observations. * : significantly different $(p<0.05)$ from the sham.

\section{Figure 4}

Etude des effets à long terme d'un implant de prolactine sur les taux d'ARNm GR dans les branchies de saumons atlantiques presmolts. Les barres d'erreurs représentent l'écart standard à la moyenne sur 4 échantillons. * : significativement différent, comparé au témoin.

In a parallel experiment, cortisol treatment was applied using silastic implants on Atlantic salmon presmolts in November (Figure 5). The gills were sampled also at 11, 13, 18 and 26 days after treatment. No significant variations of GR mRNA levels were detected in the treated fish when compared to the sham controls which suffered large fluctuations during this experiment.

\section{DISCUSSION}

Previous studies support the involvement of cortisol in stimulating hypo-osmoregulatory mechanisms associated with smoltification in Atlantic salmon. However, very few studies have been devoted to glucocorticoid receptors at the gill level, a major osmoregulatory organ. As cortisol presumably acts in interaction with other hormones such as growth hormone or IGFo, characterization of these receptors and their regulation are necessary for understanding this interaction. In the present study, analysis of these receptors was developed through the quantification of GR mRNA content in the gill tissue. Though this parameter does not really represent the "tissue receptivity " to 


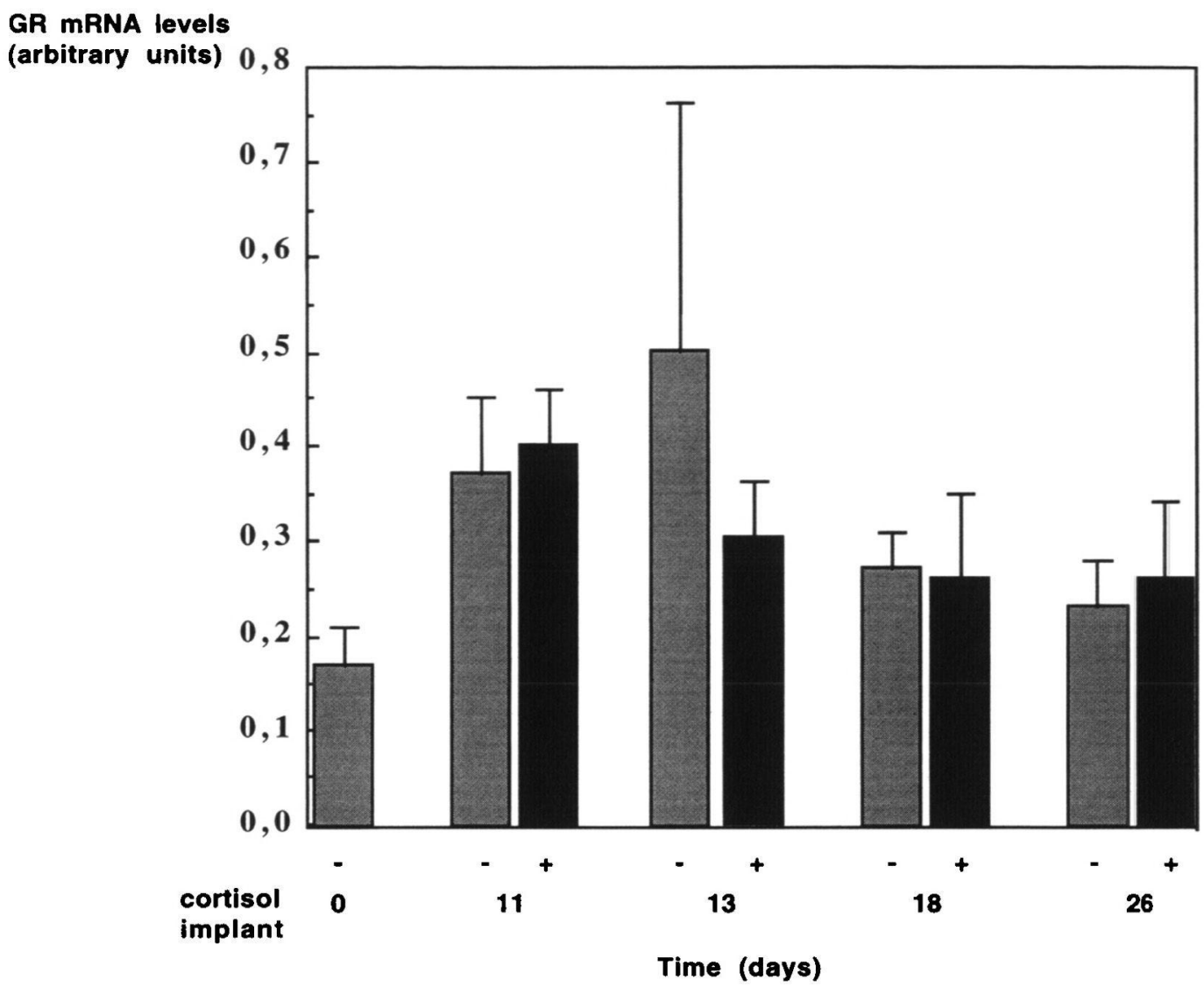

Figure 5

Long-term study of cortisol implant effects (800 $\mu \mathrm{g} / \mathrm{fish}$ ) on glucocorticoid receptor mRNA levels in the gills of presmolt Atlantic salmon (Salmo salar). Bars represent mean $+/$ - SEM of 4 observations.

\section{Figure 5}

Etude des effets à long terme d'un implant de cortisol sur les taux d'ARNm GR dans les branchies de saumons atlantiques presmolts. Les barres d'erreurs représentent l'écart standard à la moyenne sur 4 échantillons.

cortisol, it is the product of the GR gene transcription and thus constitutes an important level for receptor regulation. A first necessary step before developing a developmental study of GR transcript levels during smoltification was to ascertain that the acute stress of sampling does not lead to changes in mRNA levels. In order to test this hypothesis, the effect of a single cortisol injection on GR transcript levels was studied. Our results clearly indicated a down regulation of GR transcripts which initiated $4 \mathrm{~h}$ after cortisol treatment and became significant from $12 \mathrm{~h}$ onwards. These results are in agreement with cortisol binding studies in trout liver (LEE et al., 1992) and in Pacific salmon gill (MAULE and SCHRECK, 1991), indicating a similar down regulation of cortisol on its own receptor. A similar regulation of GR mRNA has also been reported in mammals, as shown in rat liver (SONG et al., 1991) and in human lymphocytes (ROSEWICZ et al., 1987). However, quantification of transcripts in the present study does not allow us to determine at which level the regulation occurs, whether during GR gene transcription or due to a stability of the transcripts. In any case, our results indicate that such a down regulation only occurs several hours after cortisol injection. This leads us to suggest that our technique used for collecting tissue samples probably does not modify GR mRNA levels in the gill tissue as long as the tissue sampling and collection could be performed quickly. 
Using this same sampling technique, GR transcript levels have been analyzed during smoltification in gill tissue from both parr and smolt (presmolt, smolt, postsmolt) fish. Our results clearly indicated that, in parr, GR transcript levels measured in March and early April were significantly lower than those measured in December and in late April. Moreover, during these two dates, GR mRNA levels were lower in parr when compared to December presmolts and April smolts. Interestingly, this first period corresponds to the maximum development of the hypo-osmoregulatory capacity of smolts, as indicated by the large increase in gill $\mathrm{Na}^{+} / \mathrm{K}^{+}$ATPase activity (BOEUF and PRUNET, 1985 ; PRUNET et al., 1989 ; BOEUF, 1993). It is still debated whether cortisol is or not involved during smolting in the acquisition of a hypo-osmoregulatory capacity. Several authors suggest that cortisol is regulating this hypo-osmoregulatory capacity, having stimulated $\mathrm{Na}^{+} / \mathrm{K}^{+}$ATPase activity and improved seawater adaptability in Pacific salmon species and in brown trout (RICHMAN and ZAUGG, 1987 ; Mc CORMICK and BERN, 1989 ; MADSEN, 1990). In addition, in Atlantic salmon, Mc CORMICK (1996) observed that cortisol and GH had synergistic effects in stimulating gill $\mathrm{Na}^{+} / \mathrm{K}^{+}$ATPase activity and salinity tolerance. However, LANGDON and THORPE (1984) and BOEUF et al. (1994) in Atlantic salmon and EIB and HOSSNER (1985) in rainbow trout were unable to demonstrate an effect with cortisol treatment on gill $\mathrm{Na}^{+} / \mathrm{K}^{+} \mathrm{ATP}$ ase activity, whereas BISBAL and SPECKER (1991) found significant effects of cortisol. Differences in responsiveness to cortisol may occur seasonally or according to the developmental status of the fish. Different levels of stressability of smolts still present in freshwater could also be influencing cortisol receptability and hence its effect (SIMPSON 1985). From our present data concerning GR mRNA levels in the gills, one may suggest a higher responsiveness to cortisol in smolts when compared to parr in March and early April. Nevertheless, quantification of cortisol receptor protein by binding studies or Western blot analysis with specific antibodies would be necessary before any conclusion could be drawn on this aspect.

During Atlantic salmon smoltification, significant changes in plasma hormone levels were described, mainly around the period of smoltification completion (PRUNET et al., 1989 ; BOEUF, 1993). This includes rises in GH and cortisol hormones levels. In order to characterize the endocrine factors regulating GR transcript levels in the gill tissue and stimulating their content in smolt fish, long-term treatment experiments were conducted in presmolt fish, a developmental stage where these fish have been shown to be highly responsive to hormonal treatment (BOEUF et al., 1994). Based on the above data indicating a short-term down regulation of GR transcripts by cortisol, one of the first obvious factors which may regulate GR transcript levels would be cortisol itself. Such a hypothesis would be in agreement with previous studies indicating a down regulation of cortisol on its own receptors both in fish and in mammals (see above-mentioned references). Surprisingly, in the present study, cholesterol implants containing cortisol did not lead to significant changes in GR transcript content in gill tissue. Whether this result indicates the absence of down regulation of GR mRNA during smoltification, it is presently difficult to conclude. Further studies using different doses and different periods of treatment would be needed. Simultaneously to the rise in cortisol plasma level during smoltification, PRL levels have been shown to decrease during this period (PRUNET et al., 1989). PRL being a freshwater adapting hormone, such a decrease in plasma PRL levels might be necessary for a full development of seawater adaptability during smoltification. In order to study the regulation of GR mRNA levels in the gill during smoltification, we tested the hypothesis that plasma PRL decrease may lead to a rise in GR mRNA levels in the gills. Thus, PRL treatment was applied on presmolt fish in October-November, a period where these fish have been shown to be the most sensitive to hormonal treatment (BOEUF et al., 1994). In the present study, a significant increase in gill GR mRNA levels was observed after long-term PRL treatment. The effect developed 13 days after application of PRL implants and lasted at least until day 26 . Although unexpected in the context of endocrine control of smoltification, these results are in agreement with studies on the regulation of glucocorticoid receptors by PRL in mammary gland (SHNEIDER and SHYAMALA, 1985). Using culture of mammary gland epithelial cells, these authors clearly showed that PRL was necessary to maintain GR in culture. Whether in Atlantic salmon PRL may act to maintain glucocorticoid receptors in the gill tissue independently to 
the smoltification process would deserve further studies. It would be interesting to know whether PRL treatment also increases glucocorticoid binding capacity in the gills. Our data also suggest that the increase in GR transcript levels in the gills during smoltification is regulated by another hormonal factor. In the context of smoltification, it would be interesting to test other hormones such as $\mathrm{GH}$ or thyroid hormones.

\section{CONCLUSION}

In summary, GR transcript levels have been analyzed during smoltification in gill tissue from both parr and smolt (presmolt, smolt, postsmolt) fish. Our results clearly indicated that, in parr, GR transcript levels measured in March and early April were significantly lower than those measured in December and in late April. Moreover, during these two dates, GR mRNA levels were lower in parr when compared to December presmolts and April smolts. In order to study the regulation of GR mRNA levels in the gill during smoltification, we tested the hypothesis that cortisol or PRL treatment may lead to a modification in GR mRNA levels. In the present study, cholesterol implants containing cortisol did not lead to significant changes in GR transcript content in gill tissue. Surprisingly, a significant increase in gill GR mRNA levels was observed after long-term PRL treatment. Our data also suggest that the increase in GR transcript levels in the gills during smoltification is regulated by another hormonal factor.

\section{ACKNOWLEDGEMENTS}

We are grateful to A. Gibassier and P. Chevaume (Faculty of Pharmacy, Rennes) for their kind help in preparing the cholesterol pellets. We also thank the SEMII staff for providing us the fish during this study.

\section{REFERENCES}

BISBAL G.A., SPECKER J.L., 1991. Cortisol stimulates hypo-osmoregulatory ability in Atlantic salmon, Salmo salar L. J. of Fish Physiology, 39, 421-432.

BOEUF G., PRUNET P., 1985. Measurement of gill $\mathrm{Na}^{+}, \mathrm{K}^{+}$-ATPase activity and plasma thyroid hormones during smoltification in Atlantic salmon (Salmo salar). Aquaculture, 45, 11-119.

BOEUF G., PRUNET P., LE BAIL P.Y., 1990. Un traitement à l'hormone de croissance peut-il stimuler la smoltification du saumon atlantique? Acad. Sci., série III, 75-80.

BOEUF G., 1993. In RANKIN J.C. and JENSEN F.B. (editors), Salmonid smolting : a preadaptation to the oceanic environment, Fish Ecophysiology, 9, 105-135.

BOEUF G., MARC A.M., PRUNET P., LE BAIL P.Y., SMAL J., 1994. Stimulation of parr-smolt transformation by hormonal treatment in Atlantic salmon (Salmo salar L.). Aquaculture, 121, 195-208.

CHAKRABORTY P.K., WEISBART M., CHAKRABORTI A., 1987. The presence of corticosteroid receptor activity in the gills of the brook trout, Salvelinus fontinalis. General and Comparative Endocrinology, 66, 323-332.

CHELEY S., ANDERSON R., 1984. A reproductible microanalytical method for the detection of specific RNA sequences by dot-blot hybridization. Anal. Biochem., 137, 15-19.

CHOMCZYNSKI P., SACCHI N., 1987. Single step method of RNA isolation by acid guanidinium thiocyanate-phenol-chloroform extraction. Anal. Biochem., 162, 156-159.

DUCOURET B., TUJAGUE M., ASHRAF J., MOUCHEL N., SERVEL N., VALOTAIRE Y., THOMPSON E.B., 1995. Cloning of a teleost fish glucocorticoid receptor shows that it contains a deoxyribonucleic acid-binding domain different from that of mammals. Endocrinology, 136, 3774-3783. 
EIB D.W., HOSSNER K.L., 1985. The effects of cortisol and actinomycin D injections on chloride cells and branchial $\mathrm{Na}^{+}, \mathrm{K}^{+}$-ATPase in rainbow trout (Salmo gairdneri). Gen. Comp. Endocrinol., 59, 449-452.

HOAR W.S., 1988. The physiology of smolting salmonids. In Fish physiology, HOAR W.S. and RANDALL D.J. eds, $11 \mathrm{~B}, 275-343$.

LANGDON J.S., THORPE J.E., 1984. Response of the gill $\mathrm{Na}^{+}, \mathrm{K}^{+}$-ATPase activity, succinic deshydrogenase activity and chloride cells to salt water adaptation in Atlantic salmon, Salmo salar L., parr and smolt. J. Fish Biol., 24, 323-331.

LEE P.C., GOODRICH M., STRUVE M., YOON H.I., WEBER D., 1992. Liver and brain glucocorticoid receptor in rainbow trout, Oncorhynchus mykiss : down regulation by dexamethasone. Gen. Comp. Endocrinol., 87, 222-231.

MADSEN S.S., 1990. Cortisol treatment improves the development of hypo-osmoregulatory mechanisms in the euryhaline rainbow trout, Salmo gairdneri. Fish Physiol. Biochem., 8, 45-52.

MADSEN S.S., BERN H.A., 1992. Antagonism of prolactin and growth hormone : impact on seawater adaptation in two salmonids : Salmo trutta and Oncorhynchus kisutch. Zool. Sci., 9, 775-784.

MAULE A.G., SCHRECK C.B., 1991. Stress and cortisol treatment changed affinity and number of glucocorticoid receptors in leucocytes and gill of coho salmon. Gen. Comp. Endocrinol., 84, 83-93.

Mc CORMICK S.D., BERN H.A., 1989. In vitro stimulation of $\mathrm{Na}^{+}, \mathrm{K}^{+}$-ATPase activity and ouabain binding by cortisol in coho salmon gill. Am. J. Physiol., 256, R707R715.

Mc CORMICK S.D., DICKHOFF W., DUSTON J., NISHIOKA R.S., BERN H.A., 1991. Developmental differences in the responsiveness of gill $\mathrm{Na}^{+}, \mathrm{K}^{+}$-ATPase to cortisol in salmonids. Gen. Comp. Endocrinol., 84, 308-317.

Mc CORMICK S.D., 1996. Effects of growth hormone and insulin-like growth factor I on salinity tolerance and gill $\mathrm{Na}^{+}, \mathrm{K}^{+}$-ATPase in Atlantic salmon (Salmo salar) : interaction with cortisol. General and Comparative Endocrinology, 101, 3-11.

PRUNET P., BOEUF G., BOLTON J.P., GRAHAM Y., 1989. Smoltification and seawater adaptation in Atlantic salmon (Salmo salar) : plasma prolactin, growth hormone and thyroid hormones. General and Comparative Endocrinology, 74, 355-364.

RICHMAN N.H., ZAUGG W.S., 1987. Effects of cortisol and growth hormone on osmoregulation in pre- and desmoltified coho salmon (Oncorhynchus kisutch). General and Comparative Endocrinology, 65, 189-198.

ROSEWICZ S., Mc DONALD A.R., MADDUX B.A., GOLDFINE I.D., MIESFELD R.L, LOGSDON D.C., 1987. Mechanism of glucocorticoid receptor down-regulation by glucocorticoids. J. Biol. Chem., 263, 2581-2584.

SANDOR T., DIBATTISTA J.A., MEHDI A.Z., 1984. Glucocorticoid receptors in the gill tissue of fish. General and Comparative Endocrinology, 53, 353-364.

SHNEIDER N., SHYAMALA M., 1985. Glucocorticoid receptors in primary cultures of mouse mammary epithelial cells : characterization and modulation by prolactin and cortisol. Endocrinology, 116(6), 2656-2662.

SIMPSON T.H., 1985. Epilogue. Aquaculture, 45, 395-398.

SONG L.N., YANG Y.L., XU R.B., 1991. Stress-induced regulation of glucocorticoid receptor gene expression in the rat. Receptor, 1, 207-216.

YOUNG G., BJORNSSON B.J., PRUNET P., LIN R.J., BERN H.A., 1989. Smoltification and seawater adaptation in coho salmon (Oncorhynchus kisutch) : plasma prolactin, growth hormone, thyroid hormones, and cortisol. General and Comparative Endocrinology, 74, 335-345. 